\title{
A Study on the Development Strategy of Henan's Foreign Trade Under "The Belt
}

\section{and Road" Initiative}

\author{
Jianhua $\mathrm{Liu}^{1}$, Wei $\mathrm{Li}^{1, *}$, and Song $\mathrm{Pan}^{1}$ \\ ${ }^{1}$ School of Management Engineering, Zhengzhou University, Zhengzhou 450001, China \\ 277894576@qq.com
}

Keywords: The Belt and Road Initiative, Henan Province, foreign trade, opportunities and challenges

\begin{abstract}
Under the trend of economic globalization, governments are actively involved in globalization and internationalization, China's foreign trade has also grown rapidly. In this context, President Xi Jinping proposed "The belt and road" initiative, which provides a great deal of opportunities for the development of Henan's foreign trade. This paper takes Henan Province as an example to analyse the opportunities and challenges brought by the initiative of "bringing all the way" to the development of foreign trade, and puts forward relevant suggestions for the development of foreign trade in Henan Province.
\end{abstract}

\section{INTRODUCTION}

In 2013, when President Jinping Xi visited the four countries of Central Asia and Indonesia, he proposed the "one belt, one road" initiative conception, "one belt" refers to the "Silk Road economic belt", "one road" refers to "the 21st century maritime silk road." On March 28, 2015, the National Development and Reform Commission, the Ministry of Foreign Affairs and the Ministry of Commerce jointly issued the "Vision and Action to Promote the Silk Road Economic Belt and the 21st Century Maritime Silk Road", then, "one belt, one road" initiative has been put on the agenda. This has been more than 60 countries along the "one belt, one road", the total population of these countries is about 44 billion people, accounting for about $63 \%$ of population in the world; the total economic output of these countries is about 21 trillion US dollars, accounting for about $29 \%$ of economic output in the world (Youling Wang and Weiwei Chen, 2014). With "one belt, one road" initiative put forward, it has Strengthen the interconnection of these countries' partnership, promote the development of domestic foreign trade industry, and thus promote domestic economic growth. Henan is located in the center of our country, it is an important birthplace of the Chinese nation and Chinese civilization. Historically, Henan had been the China's political, economic and cultural center and has played an important supporting role in the development and prosperity of the ancient Silk Road. Since the reform and opening up, Henan's comprehensive economic strength has improved significantly, open economy has been accelerating development, and Henan has been keep the close relationship with "one belt, one road" countries. Therefore, Henan Province should seize the "one belt, one road" strategic opportunities, and vigorously promote the development of foreign trade in Henan.

\section{CURRENT SITUATION OF FOREIGN TRADE IN HENAN PROVINCE}

In recent years, Henan foreign trade has developed rapidly, the total import and export trade has been rising year by year, the overall trend of foreign trade has shown a good development trend, See Figure 1 and Figure 2. According to customs statistics, in 1996 the total import and export trade in Henan Province was only 16.319 billion yuan, which is due to 1990 - 2000 domestic enterprises are still in the initial stage of international investment; With the gradual opening up of international policy and the development of economy in Henan Province, a large number of Henan enterprises begin to participate in the international market competition, making the total import and export trade in Henan Province in 2006 rose to 78.091 billion yuan; In recent years, Foxconn enterprises settled in Henan Province, which is a great impetus to the development of foreign trade in Henan Province; 2016, the total import and export trade in Henan Province is more than 470 billion yuan, reaching at 471.47 billion yuan and creating a Henan milestone of foreign trade import and export (Shiyan Wang and Zhipeng Jia, 2016), Henan Province as the inland provinces first merging in the country's top 10 foreign trade. Although in recent years, Henan Province has made remarkable achievements in foreign trade, but from the customs statistics, Foxconn as the representative of the smart phone industry has great impact on foreign trade in Henan Province, that is to say, processing trade, like mobile phones and other emerging industries, have replaced the traditional industries as a pillar industry in Henan foreign trade; In 2016 Henan Province, the total import and export trade volume of processing trade reached 321.419 billion yuan, accounting for $68.2 \%$ of the total import and export value in Henan Province(Shiyan Wang and Zhipeng Jia, 2016). At the same time, traditional labor-intensive exports continued to weaken. In the market structure, the main trading partners in Henan import and export trade are the United States, the European Union, South Korea, 
Japan and China Taiwan. In 2016, the bilateral trade volume with the United States, the European Union, South Korea, Japan and China Taiwan was 86.403 billion yuan, 73.951 billion yuan, 42.388 billion yuan, 41.432 billion yuan and 38.17 billion yuan (Shiyan Wang and Zhipeng Jia, 2016).

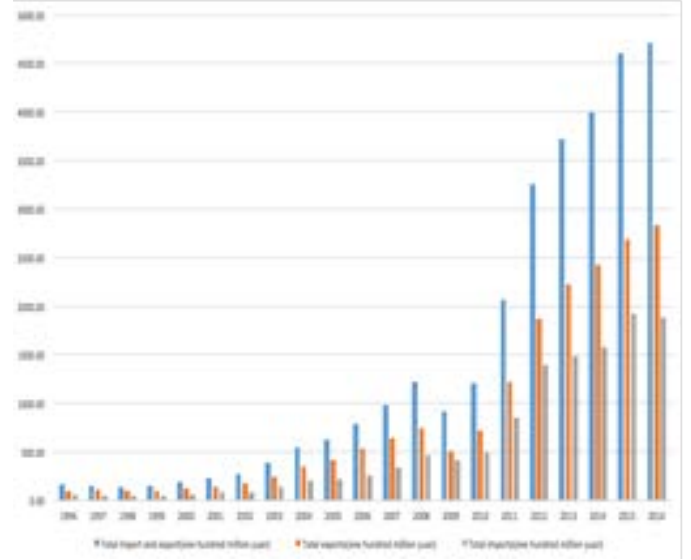

Fig.1 1996-2016 Henan Province foreign trade import and export quota chart

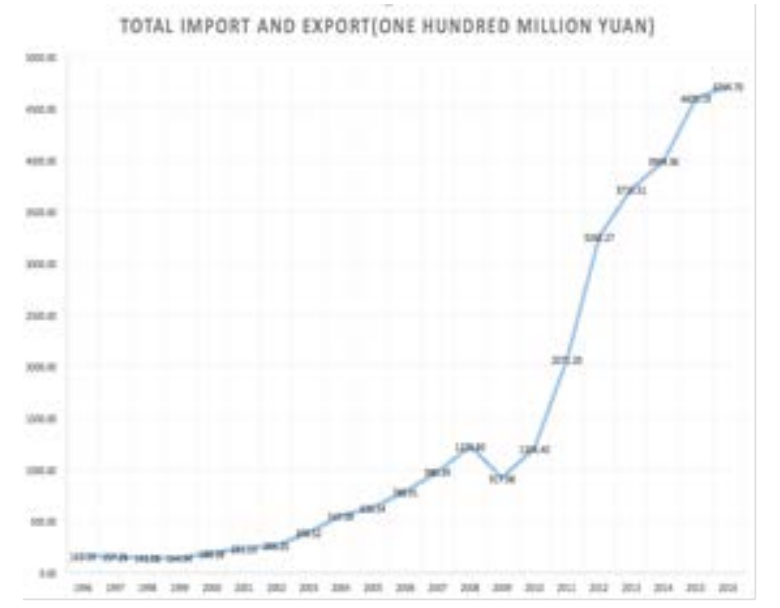

Fig.2 1996-2016 Henan Province, the total foreign trade trends

\section{OPPORTUNITIES AND CHALLENGES FACED BY HENAN'S FOREIGN TRADE UNDER "ONE BELT, ONE ROAD" INITIATIVE}

\subsection{Opportunity}

\subsubsection{Infrastructure construction under "the belt and road" initiative}

The "interconnection" of the infrastructure is an important part of the "one belt, one road " interconnection system, and it is responsible for improving the hardware requirements for the development of the countries near the "one belt, one road". The scope of infrastructure includes energy (production, transportation and distribution of natural gas, electricity and other energy), information and communication technology (ICT), transportation (aviation, railways, highways and ports), water (urban drinking water system construction, sewage collection and treatment, etc.), that is say, the infrastructure includes not only bridge construction, as well as oil and gas pipelines, transmission networks, cross-border cable construction (Meng Liao, 2015). The Asian Development Bank (ADB) and the Asian Development Bank Research Institute jointly released the "Asian Infrastructure Construction" in 2009. According to the report, total demand for infrastructure investment in Asia is projected at $\$ 8.28$ trillion in $2010-2020$, of which the country's investment demand is about $\$ 8$ trillion and the regional investment demand is \$ 280 billion (Mengmeng $\mathrm{Fu}, 2014)$. According to the OECD forecast, 2013-2030 global infrastructure investment demand will reach 55 trillion in order to meet the needs of global economic development. As an advocate of the "one belt, one road" initiative, China will actively participate in the "one belt, one road" infrastructure construction with its experience, capital and technology accumulated over 30 years from reform and opening up. "One belt, one road" has accelerated the infrastructure areas' cooperation between China and the countries about the built of railway, highway, port and other infrastructure areas, which is beneficial for Chinese enterprises to expand the international market provides an important opportunity. While the construction of transport infrastructure, energy infrastructure and communications infrastructure requires a lot of labor, Henan Province as China's first large province of population and the province of labor output, is bound to take the "one belt, one road" strategic express, to undertake more international infrastructure projects and create more migrant workers, comprehensive promotion of foreign trade in Henan Province.

\subsubsection{Foreign trade cooperation under "the belt and road" initiative}

These countries along the "one belt, one road" have a large population, vast territory, richness resources, and they are important trading partners with China. China's traditional trade advantages of goods is the laborintensive processing and manufacturing industry, part of the country's trade advantage lies in resource-intensive products, such as Iran's oil export trade, Malaysia's latex export trade, and some countries are focused on agricultural exports, such as Cambodia and other countries. It can be seen that the economic structure of these countries along the way has a strong complementarity, so the potential of trade cooperation among these countries is huge. In 2016, the sum of GDP in the "one belt, one road" countries accounted for $16.0 \%$ of the world's GDP, $43.4 \%$ of the world's population and $21.7 \%$ of the total global trade. In 2016, the trade volume between china and these countries was 953.59 billion US dollars, accounting for $25.9 \%$ of China's total trade in goods, and reflecting the "one belt, one road" trade cooperation was in a good momentum under the background of slow recovery of the global economy (Rongzhen Yang and Ruizhe Jia, 2017). In order to strengthen the trade cooperation with the countries along "one belt, one road", Henan Province in November 2015 introduced the " Implementation plan about Henan Province to participate in the construction of the Silk Road economic zone and the 21st century Maritime Silk Road ", to support the development of equipment 
manufacturing industry and other advantages industrial, which is useful for Henan Province industry go into the world. Over the years, Henan's main partners of foreign trade is the United States, the European Union, South Korea, Japan and China Taiwan, "one belt, one road" initiative and the implementation of relevant policies is bound to deepen the trade cooperation between Henan Province and countries along the line, strengthen trade relations with countries along the line, expand the foreign trade network in Henan Province, finally increase the total import and export trade in Henan.

\subsubsection{Trade cooperation mechanism under "the belt and road" initiative}

Henan Province is located in the inland areas, compared to the eastern coastal areas in china, foreign trade development lags behind. Moreover, "one belt, one road" involving 65 countries and Egypt's Sinai Peninsula. There are huge differences in the economic system, political system, national system, customs, culture, language and religion of these countries, which has restricted the trade cooperation between Henan Province and the countries or regions along the line. However, the "one belt, one road" initiative has gradually established a cooperative and win-win trade cooperation mechanism, alleviating the difficult situation of Henan Province's foreign trade to develop new foreign trade development space. June 14, 2017, General Secretary Xi met with the Prime Minister of Luxembourg clearly put forward the opinion about deepening of the "one belt, one road" within the cooperation framework of financial, production and other areas; September 2017, Henan Provincial People's Government Office issued a "construction program to promote Zhengzhou Luxembourg air Silk Road ", to promote the construction of bilateral trade cooperation mechanism, expand bilateral cooperation in the air transport, economic and trade industries, financial services, cultural exchanges and other aspects, and promote the promotion of Henan trade volume.

\subsection{Challenges}

\subsubsection{The threat of regional trade protectionism}

World Trade Organization published report in July 2017 shows that from mid-October 2016 to mid-May 2017, members of the Group of 20 countries launched a total of 74 trade restrictions(Trade restrictions include the addition or raising of tariffs, the strengthening of customs supervision and the implementation of quantitative restrictions, etc.), average about 11 trade restrictions per month, compared to the periods from mid-October 2015 to mid-May 2016 monthly more than 20 trade restrictions, it has been reduced, but the extent of trade protectionism on Henan exports still should not to be overlooked. In the background of global economic still at the downturn trend, many countries and regions begin to implement trade protection, set up trade barriers, and the introduce anti-dumping means to restrict imports to protect their domestic goods' market share.

\subsubsection{Weak foreign trade in Henan}

In recent years, the total foreign trade of Henan
Province in the central six provinces ranked first, but compared to the coastal provinces, there is still a big gap. In 2016, the total import and export volume of Henan Province was US \$ 71.19 billion, at same year, the total import and export volume of Jiangsu Province was US \$509.53, the total import and export volume of Zhejiang Province was US \$336.50, the total import and export volume of Guangdong Province was US \$955.51, thus, Henan Province Foreign Trade need to be improved. China is stretched in the construction of "one belt, one road", for example, only three Central Asian countries 2013-2022 energy investment will need 36 billion US dollars (Yueqin Lin, 2015), the "one belt, one road" construction task that Henan as a province could took is more limited.

\subsubsection{Irrational foreign trade structure}

Henan Province, foreign trade from 1996 to 2016 to maintain the trend of rapid growth, the reason is mainly driven by the large input of resources and other resource elements. Therefore, with the vanish of "demographic dividend" of "China-made" in recent years, Henan Province's foreign trade will lack the driving force for sustainable development. For example, the total import and export trade amounted to 46,001.9 million yuan in Henan province, the general trade amount is 121.151 billion yuan, accounting for $26.3 \%$ of the total import and export trade; Processing trade is 3160.66 billion yuan, accounting for $68.71 \%$ of total import and export trade; Foreign contracted exports only 34.44 billion yuan. 2015, Henan Province, the processing trade in the total import and export trade accounted for $68.71 \%$, of which Foxconn enterprises and mobile phone projects in the processing trade occupies a great component. Henan Province, foreign trade is also increasingly dependent on mobile phones and other emerging industries pro-cessing trade, the structure of commodity imports and export is increasingly imbalance (Jingxuan Shen, 2014).

\section{SUGGESTIONS ON THE DEVELOPMENT OF HENAN FOREIGN TRADE UNDER "ONE BELT, ONE ROAD" INITIATIVE}

\subsection{Optimize the structure of foreign trade, help economic growth}

First of all, we should proceed from the concept of government development, change the traditional way of extensive investment in labor force, capital, land and other elements, use the factors of independent intellectual property rights, high technology and other factors to driving Henan economic growth. Therefore, for the optimization of foreign trade structure in Henan Province, the Government should support resources to the foreign trade enterprises of ownership of independent property rights, the core technology, and encourage foreign trade enterprises pay more money on product technology, product patents; At the same time, the government should strengthen the training of foreign trade enterprises head of the "going out" strategic awareness, to encourage local construction units to undertake international infrastructure projects; 
Accelerate the development of Zhengzhou Airport, Zhengzhou cross-border e-commerce comprehensive test area, so that cross-border trade and export industry can form a mutual promotion and coordination of the virtuous circle, jointly promote the development of foreign trade in Henan Province.

\subsection{Build mutually beneficial and win-win foreign trade platform, to achieve trade facilitation}

The Henan government can through bilateral or regional negotiations with the "one belt, one road" countries or region to establish mutually beneficial and win-win trade cooperation mechanism. For these countries which implement trade protections or set up trade barriers, we can through a reasonable and feasible way to eliminate its targeted trade restrictions. Based on the "one belt, one road" initiative, Henan province can establish partnership with these countries, and expand Henan's foreign trade partners network space, jointly develop infrastructure projects with these countries through the Silk Road economic belt, and promote multilevel, multi-faceted comprehensive trade cooperation among these countries.

\subsection{Improve the company's opening up awareness}

There is a huge difference between Henan Province and domestic coastal areas in foreign trade, one of the important reasons for this difference is that the coastal areas of China are exposed to foreign trade early than Henan, because the coastal areas of China have the advantages of geographical factors, so they can keep up with the wave of global economy to achieve rapid development, and Henan Province is located in China's inland, the public has long been a lack of open awareness, thus the development of foreign trade is also in the backward situation compared to the coastal areas. Therefore, the government departments can start from raising the awareness of the opening up of enterprises, increase the support to foreign trade enterprises in the province, encourage advantages enterprises to actively participate in the international market competition, only in this way can improve the development of foreign trade in Henan Province.

\subsection{Sign a strategic cooperation agreement to enhance international competitiveness}

As the comprehensive strength of foreign trade in Henan Province is weak compared to the coastal provinces, so that in the "one belt, one road" infrastructure construction projects, Henan's international competitiveness still laid in a weak situation. Thus, we can establish a strategic cooperation agreement with China's other provinces, participation in international competition with other provinces, enhance the international competitiveness of corporate groups, enhance the brand effect of China's foreign trade exports, and gradually pull up the visibility of foreign trade enterprises in Henan. For small and medium-sized foreign trade enterprises in Henan Province, we can encourage them to carry out strategic reorganization, resource integration, and establish the industrial clusters of which have international influence, finally overstate the strength of foreign trade in Henan Province.

\subsection{Cultivate high - quality foreign trade talents, strengthen the construction of foreign trade team}

In order to ensure the healthy development of foreign trade industry, we must adopt talent strategy, cultivate a number of high-quality foreign trade talent, at the same time, absorb the high-quality talent return from abroad, only in this way, foreign trade personnel will be actively involved in the development of foreign trade in Henan Province, inject vitality and impetus to the development of foreign trade in Henan province, finally promote the development of foreign trade in Henan Province.

\section{REFERENCES}

[1] Jingxuan Shen, 2014. Henan Province's foreign trade problems and countermeasures, Henan University.

[2] Meng Liao, 2015. Opportunities and Challenges for Chinese Enterprises to Go Out in the Background of "One Belt, one Road", Economic Perspective. (09), pp.30-33.

[3] Mengmeng Fu, 2014. Asia Infrastructure Investment for \$ 8 trillion in 10 Years - China Opportunities under Asia-Pacific Dreams, China Times.

[4] Rongzhen Yang, Ruizhe Jia, 2017. Opportunities and Challenges for Trade Cooperation Under "One Belt, one Road", GuangmingDaily.

[5] Shiyan Wang, Zhipeng Jia, 2016. 7-1 basic situation of foreign economic and trade, Henan Statistical Year-book.

[6] Shiyan Wang, Zhipeng Jia, 2016. 7-2 total import and export, Henan Statistical Yearbook.

[7] Shiyan Wang, Zhipeng Jia, 2016. 7-3 the total amount of import and export of various groups, Henan Statistical Yearbook.

[8] Shiyan Wang, Zhipeng Jia, 2016. 7-4 the total import and export: Henan to a number of countries (regions), Henan Statistical Yearbook.

[9] Youling Wang, Weiwei Chen, 2014. To build a new pattern of opening up to promote the "one belt, one road" initiative, Guangming Daily.

[10] Yueqin Lin, 2015. "One Belt, one Road" ideas: Challenging and coping, Journal of Hunan University of Finance and Economics. 31(02), pp.5-17. 